\title{
1 Evolution of dolomite composition and reactivity during biomass 2 gasification
}

3 Maxime Hervy $^{\mathrm{a}}$, Roberto Olcese ${ }^{\mathrm{a}}$, Mohammed M Bettahar ${ }^{\mathrm{b}}$, Martine Mallet ${ }^{\mathrm{c}}$, Aurélien Renard ${ }^{\mathrm{c}}$,

4 Libeth Maldonado ${ }^{a}$, Damien Remy ${ }^{a}$, Guillain Mauviel ${ }^{a}$, Anthony Dufour ${ }^{\mathrm{a}, *}$

5 a LRGP, Université de Lorraine, CNRS, ENSIC, 1, Rue Grandville 54000 Nancy, France

6 b Institut Jean Barriol, L2CM, Université de Lorraine, CNRS, Faculté des Sciences et de la

7 Technologie Boulevard des Aiguillettes, BP 7036, 54506 Vandœuvre Cedex, France

$8{ }^{\mathrm{c}}$ Institut Jean Barriol, LCPME, Université de Lorraine, CNRS, 405, rue de Vandoeuvre, F-54600

9 Villers-lès-Nancy, France

$10 *$ corresponding author at: anthony.dufour@univ-lorraine.fr

\section{Abstract}

12 Dolomite is a cheap and robust catalyst used for biomass gasification, but its deactivation under 13 relevant conditions of pilot-scale gasifiers has still been poorly understood. For this reason, the 14 catalytic activity of fresh and used dolomites produced from an industrial air-blow fluidized bed was investigated. Fresh and used dolomites were characterized by BET, SEM-EDX, XPS, ICP-

16 MS, XRD, TPD and TPO. Benzene steam reforming was selected as a surrogate reaction of $\operatorname{tar}$ 17 conversion in order to probe the reactivity of the two dolomites. The activity of used dolomite was $25 \%$ lower than that of fresh dolomite. This difference could be explained by: (1) the

19 deposition of a Si-based layer from biomass ashes at the surface of used dolomite, and (2) the 20 production of coke during gasification. The reaction mechanism of benzene steam reforming 21 over fresh and used dolomites was discussed. For used dolomite, the Si and coke depositions 22 reduced the availability of the active sites $(\mathrm{CaO}, \mathrm{MgO})$ thus lowering the conversion of benzene. 23 These deposits could also inhibit the interactions between $\mathrm{CaO}$ and $\mathrm{MgO}$ and enhance the 24 formation of a stable coke. 


\section{Keywords}

28 biomass; dolomite; gasification; syngas; tar; up-grading.

\section{Outline (only for reviewers)}

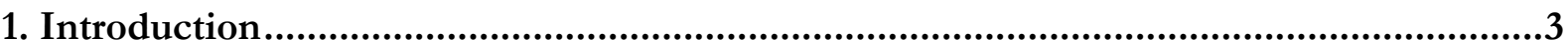

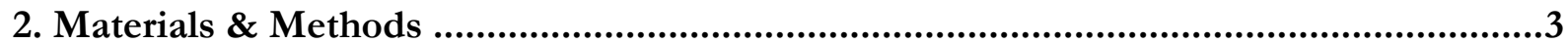

2.1. Presentation of the dolomite samples.

2.2. Characterizations of the catalysts

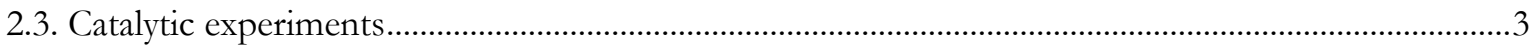

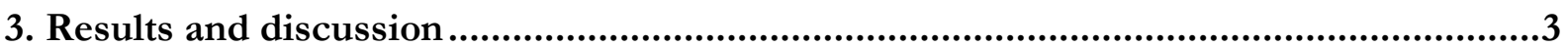

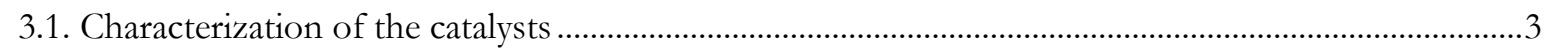

3.1.1. Morphology of particles and chemical composition of the bulk catalysts by ICP..........................................

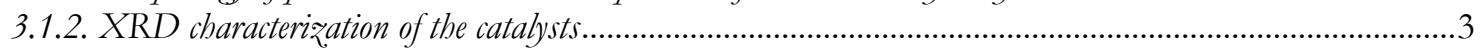

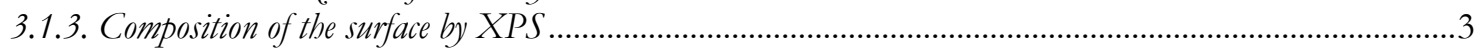

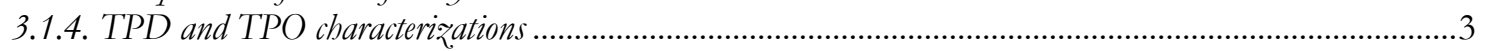

3.2. Steam reforming of benzene over fresh and used dolomites ................................................................. 3

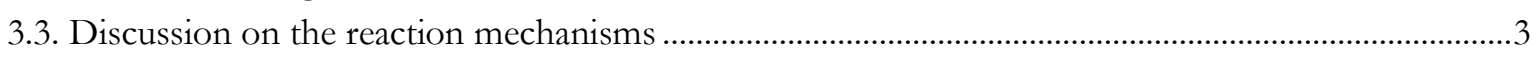




\section{Introduction}

Renewable alternative routes for energy production appear as an important challenge to reduce the greenhouse gases emissions while meeting the growing world energy demand. Biomass gasification is an attractive way to convert a renewable resource into several energy carriers, such as substitute natural gas, bio-hydrogen, or Fischer-Tropsch biofuel [1]. Nevertheless, the removal of the syngas pollutants (such as tars) is required before further valorization, and this step remains the major issue in the development of gasification processes. Tar is formed by pyrolysis reactions combined with incomplete oxidation reactions in gasifiers [2-4] and is the most problematic pollutant contained in the syngas [2]. Tar is composed of a wide variety of aromatic and oxygenated compounds classified in different classes depending on their properties [5] or their thermal history (primary, secondary and tertiary tar) [2]. These compounds can condense along the process chain thus impeding syngas valorization. The concentration of tar must be drastically reduced in order to meet the standards required for syngas ranging from about $50 \mathrm{mg} / \mathrm{Nm}^{3}$ (or a dew point lower than $35^{\circ} \mathrm{C}$ for engine [6]) to 0.1 $\mathrm{mg} / \mathrm{Nm}^{3}$ (for Fischer-Tropsch synthesis) [7]. In addition, tar in syngas considerably reduces the cold gas efficiency of gasifiers. Indeed, benzene can represent $0.5 \%$ of biomass LHV in air dense fluidized bed gasifier [3].

For these reasons, the catalytic conversion of tar into gaseous products $\left(\mathrm{CO}, \mathrm{H}_{2}, \mathrm{CH}_{4}\right)$ is of tremendous importance for improving the gasification processes. The main drawbacks of the catalytic methods are the cost of the catalysts and their deactivation. This topic has been intensively studied over the past 30 years, and several reviews have reported the main conclusions [8-20]. These studies focused on the conversion of real biomass tars, or tar surrogate molecules. Benzene, toluene and naphthalene are often considered as surrogate tar compounds due to their significant concentration in syngas and to their stability $[9,21,22]$. Benzene is the most important aromatic compound present in the syngas and the most stable one [22-24]. For this reason it is a good surrogate of tertiary (high temperature) tar.

A large variety of catalysts were tested for tar decomposition: chars [25-28], zeolites [29,30], iron oxides [31], noble metals [32-37], alkaline and alkaline earth metals (AAEM) [38,39], nickel catalysts [40,41], clay minerals [13], olivine [42,43], and calcined rocks (magnesite, calcite, dolomite) [44-46]. Carbonate rocks, such as dolomite, were identified as promising catalysts due their abundance and low-cost [47-51].

Dolomite is a natural magnesium ore $\left(\mathrm{MgCO}_{3} \cdot \mathrm{CaCO}_{3}\right)$ composed of a mixture of calcium carbonate and magnesium carbonate at a concentration ratio of nearly 1:1. A tremendous number of articles highlighted that dolomite is an active catalyst for tar removal [48,52-64]. A calcination 
step is required to increase the catalytic activity of dolomite by eliminating $\mathrm{CO}_{2}$ and transforming $\left(\mathrm{CaMg}\left(\mathrm{CO}_{3}\right)_{2}\right)$ into active $\mathrm{CaO}$ and $\mathrm{MgO}$ [65]. $\mathrm{CaO}$ is known to be more active than $\mathrm{MgO}$ in tar cracking reactions and is mainly responsible for the high activity of calcined dolomite [66]. However, a synergistic interaction between $\mathrm{CaO}$ and $\mathrm{MgO}$ plays an important role in the activity of dolomite. Indeed, catalysts based on mechanical mixtures of $\mathrm{MgO}$ and $\mathrm{CaO}$ have presented a better performance than $\mathrm{CaO}$ alone [67]. In addition, dolomite was proved to be more active than magnesite $\left(\mathrm{MgCO}_{3}\right)$ and calcite $\left(\mathrm{CaCO}_{3}\right)$ for tar reforming [50,64]. The higher activity of dolomite is mainly explained by the lower deactivation by coke deposition, as a result of the presence of $\mathrm{MgO}$ which inhibits the formation of stable carbonaceous materials at the surface of $\mathrm{CaO}$, and which promotes the formation of less stable carbon species that are easily gasified [68]. Therefore, the deactivation of $\mathrm{CaO}$ active sites by coke deposition is reduced. The presence of iron in dolomites is also expected to play a role in the steam reforming of tar as well as in the water-gas shift reaction [56,64].

Some articles specifically studied the decomposition of benzene [52,54], toluene [69-71] and naphthalene $[53,72]$ over calcined dolomite. The tests were conducted at $700-900{ }^{\circ} \mathrm{C}$ under different atmospheres: steam, carbon dioxide or syngas mixtures. The benzene decomposition reactions mainly generated $\mathrm{H}_{2}$ and $\mathrm{CO}_{2}$, while $\mathrm{CO}$ was a minor product and was generated in lower amount with rising temperature. These reactions were inhibited by hydrogen which may be dissociatively adsorbed on the metal-oxide adsorption sites, thus preventing the tar access to adsorption sites [73,74]. The $\mathrm{CO}_{2}$ concentration in the syngas and the temperature strongly influence the activity of dolomite. Indeed, the dolomite can be carbonated (depending on the thermodynamic equilibrium of $\mathrm{CO}_{2} / \mathrm{CaO} / \mathrm{CaCO}_{3}$ ) which results in the decrease of its catalytic activity for tar cracking [47,55]. Dolomite can be deactivated by hydration and carbonation reactions [75].

Syngas cleaning processes are classified in two types depending on their location; either in the gasifier (primary methods) or downstream of the gasifier (secondary methods) [77]. Secondary methods may be slightly more efficient than primary ones but a specific catalytic cracking reactor is required thus increasing the investment and operating costs of the gasification unit. Dolomite as in-bed material was shown to be an efficient catalyst for tar cracking [49] allowing the production of a relatively clean syngas. For this reason, dolomite is often used as bed material in gasification and notably in many recent studies [78-81]. In fluidized bed gasifier, dolomite is in contact with biomass particles, and a modification of its surface properties is likely to occur. These modifications could change the long-term 
115 catalytic activity of "used dolomite" for tar cracking, thus modifying the syngas yield and quality.

116 This crucial topic has never yet been explored for dolomite whereas it has been extensively 117 studied for olivine. Indeed, several studies showed that olivine is coated by ash materials during 118 biomass gasification and this ash layer considerably increases the reactivity of olivine for tar cracking and WGS reactions [82-88]. This present work reveals that the impact of ashes may be very different for dolomite than for olivine.

To the best of our knowledge, this work presents for the first time the effect of dolomite aging under significant gasification conditions (in a pilot plant) on tar conversion. Dolomites before and after gasification of biomass were characterized by complementary methods (BET, SEM-EDX, XRD, XPS, TPO, TPD). Then the reactivity of these 2 dolomites (pristine and used) was studied by a "probe" key reaction of tar conversion which is the steam reforming of benzene. Finally the mechanisms of benzene steam reforming over dolomites are discussed.

\section{Materials \& Methods}

\subsection{Presentation of the dolomite samples}

The dolomite originating from Cantabria (Spain) was calcined at $1000^{\circ} \mathrm{C}$ for few hours before being used as a catalyst in a biomass gasification plant at Portalegre, Portugal (EQTEC technology) [89]. The gasification reactor was a dense fluidized bed operated at a temperature of $750^{\circ} \mathrm{C}$ for 10 days using air as gasifying agent. Biomass was a mixture of wood $(70 \%)$ and miscanthus $(30 \%)$ and was fed in the reactor at a flow-rate of $50 \mathrm{~kg} / \mathrm{h}$. The analysis of biomass is presented in supplementary material. The dolomite samples were denoted as "fresh" after calcination, and "used" after gasification. Both samples were sieved to particle sizes from 100 to $250 \mu \mathrm{m}$.

\subsection{Characterizations of the catalysts}

The morphology of fresh and used dolomite materials was studied on a scanning electron microscope (SEM) JEOL model JSM-6490LV combined with energy dispersive X-ray spectroscopy (EDX) to analyse the chemical composition of the surface.

For inductively coupled plasma mass spectrometry (ICP-MS) analysis of the bulk, the samples were dissolved in lithium metaborate $\left(\mathrm{LiBO}_{2}\right)$ and nitric acid $\left(\mathrm{HNO}_{3}\right)$ solutions following the CNRS-SARM procedure [90].

144 The crystalline structure of the fresh and used dolomites was analysed by X-ray 145 diffraction (XRD) measurements. XRD analyses were performed at room temperature using a 146 Philips Panalytical X'Pert Pro MPD diffractometer equipped with Xcelerator detector. XRD 
147 patterns were collected with a $\mathrm{CuK} \alpha$ radiation source operating at $40 \mathrm{kV}$ and $40 \mathrm{~mA}$. The 148 diffraction pattern was collected in the range $2 \theta=10-80^{\circ}$, with a step size of $0.016^{\circ}$ in $2 \theta$, and a 149 scan speed of $1.7 \mathrm{~min}^{-1}$.

150 XPS analyses were performed using a KRATOS Axis Ultra X-ray photoelectron 151 spectrometer (Kratos Analytical, Manchester, UK) equipped with a monochromatic Al K $\alpha$ X-ray 152 source $(\mathrm{h} \nu=1486.6 \mathrm{eV})$ operated at $150 \mathrm{~W}$. Spectra were collected at normal $\left(90^{\circ}\right)$ take-off angle 153 and the analysis area was $700 \times 300 \mu \mathrm{m}$. The base pressure in the analytical chamber was $10^{-9} \mathrm{mbar}$

154 during XPS measurements. Wide scans were recorded using an analyser pass energy of $160 \mathrm{eV}$, 155 while narrow scans were obtained using a pass energy of $20 \mathrm{eV}$ (instrumental resolution better 156 than $0.5 \mathrm{eV})$.

157 BET areas were determined by the one-point method using adsorbed nitrogen at $77 \mathrm{~K}$ in a 158 Micromeritics TriStart II instrument. The solids were previously degassed under vacuum at room 159 temperature overnight.

160 Temperature Programmed Desorption (TPD) and Temperature Programmed Oxidation 161 (TPO) were performed by heating the dolomite samples at $850^{\circ} \mathrm{C}$ under a $30 \mathrm{NmL} / \mathrm{min}$ flow of 162 pure nitrogen (TPD) or air (TPO). A 2.5g dolomite sample was placed in a quartz U-reactor 163 (internal diameter $=10 \mathrm{~mm}$ ) heated by an electrical furnace at $5^{\circ} \mathrm{C} / \mathrm{min}$ to $850^{\circ} \mathrm{C}$. The exhaust gas 164 was analysed online by a micro-gas chromatograph ( $\mu \mathrm{GC}$ ) (SRA Instrumentation R3000).

\section{2.3. Catalytic experiments}

166 The experiment set-up has been presented previously [91]. Catalytic experiments were 167 conducted on a fixed bed quartz reactor (internal diameter $10 \mathrm{~mm}$ ) placed in an electric oven. The 168 catalytic bed was supported by a quartz sintered plate. A thermocouple was positioned within the 169 bed of dolomite. The inlet gas composition was controlled by mass flow controllers 170 (Bronkhorst). Benzene (supplied by Fluka, 99.9\% purity) and demineralised water were added in 171 the gas mixture by two syringe pumps and vaporised in a vaporisation chamber, swept by 172 nitrogen and connected through a heated line to the catalytic bed. At the outlet of the catalytic 173 bed, permanent gases were analysed on-line with a $\mu$-GC Varian 490 equipped with 4 modules.

174 The outlet was also connected to a heated sampling line and to a heated sampling loop for on175 line analysis of benzene by a GC/FID.

176 The operating conditions of the catalytic tests were chosen in order to obtain a contact 177 time similar to the one used in the industrial gasification fluidized bed of EQTEC. The mass of 178 catalyst was $3.0 \mathrm{~g}$ and the total gas flow rate was set at $45 \mathrm{NmL} / \mathrm{min}$. These conditions were set to 179 be consistent with the industrial fluidized bed conditions (mass of fluidized dolomite bed and 180 total outlet syngas flow rate). The benzene inlet concentration was $0.5 \mathrm{vol} \%$ which corresponds to 
181 the content usually measured in the syngas [3]. Catalytic tests were performed at 800,850 and

$182900^{\circ} \mathrm{C}$ without applying pre-treatment to the materials. The conversion of benzene was constant 183 over time on stream and the value presented is an average of several points (GC/FID analysis) 184 over more than 50 minutes.

185 The benzene conversion $\left(\mathrm{X}_{\mathrm{B}}\right)$ was calculated according to Eq.1, where $\dot{\boldsymbol{n}}_{\mathrm{B}}^{\boldsymbol{i n}}$ is the molar 186 flow rate of benzene feeding the reactor, and $\mathrm{n}_{\mathrm{E}}^{\text {out }}$ the molar flow rate of benzene leaving the 187 reactor.

\section{Results and discussion}

193 3.1. Characterization of the catalysts

194 3.1.1. Morphology of particles and chemical composition of the bulk catalysts by ICP

Table 1 compares the values of BET surface area of fresh and used dolomite samples.

197 For fresh dolomite, the measured values were not high enough to be accurate. Both types of catalysts exhibited low BET surface areas $\left(<20 \mathrm{~m}^{2} / \mathrm{g}\right)$. However, a slight increase of the BET surface area was observed for used dolomite samples.

Table 1. BET surface area of dolomite and olivine.

\begin{tabular}{cc}
\hline Catalyst & BET $\left(\mathbf{m}^{2} / \mathbf{g}\right)$ \\
\hline Fresh dolomite & 0.4 \\
Used dolomite & 19.5 \\
\hline
\end{tabular}

201 SEM images and EDX analyses of dolomite materials are presented in Figure 1 and Table 2. 202 EDX analysis was averaged on various particles. Dolomite is a natural material and presents an 203 average composition of about 17\% Mg and 34\% Ca. After its use as a bed material in the

204 fluidised bed reactor, the surface of used dolomite is enriched by inorganic elements initially 205 contained in the biomass. The surface of dolomite particles is coated by a layer of ashes and 206 becomes smoother as shown on Figure 1. The mechanisms of coating are out of the scope of the 207 present study and have been previously studied in details [3,92,93]. The coating behaviour 
depends on gasification conditions and on the composition of the bed, the reactor walls and the 209 ashes of biomass.

210 Si and P are not detected on fresh dolomite, but their concentrations at the surface of used 211 dolomite are of about 2.5 and $3.7 \mathrm{wt} . \%$ respectively (Table 2). SEM-EDX is only a first qualitative 212 approach of dolomites chemistry. For this reason, ICP-MS, XRD, XPS and TPD/TPO analyses 213 were performed in order to study more deeply the chemical composition of the catalysts.

Table 2. SEM-EDX analysis of fresh and used dolomite

\begin{tabular}{|c|ccc|ccc|}
\cline { 2 - 7 } \multicolumn{1}{c|}{} & \multicolumn{3}{c}{ Fresh dolomite } & \multicolumn{3}{c|}{ Used dolomite } \\
\hline Elements (wt.\%) & Min & Average & Max & Min & Average & Max \\
\hline $\mathrm{O}$ & 44.7 & $\mathbf{4 9 . 4}$ & 59.8 & 41.1 & $\mathbf{4 8 . 1}$ & 54.8 \\
$\mathrm{Mg}$ & 1.6 & $\mathbf{1 7 . 0}$ & 36.2 & 3.6 & $\mathbf{5 . 3}$ & 7.5 \\
$\mathrm{Ca}$ & 19.1 & $\mathbf{3 3 . 7}$ & 48.5 & 37.0 & $\mathbf{4 1 . 9}$ & 46.6 \\
$\mathrm{P}$ & nd & $\mathbf{n d}$ & $n d$ & 2.2 & $\mathbf{2 . 5}$ & 2.7 \\
$\mathrm{Si}$ & nd & $\mathbf{n d}$ & nd & 3.3 & $\mathbf{3 . 7}$ & 4.1 \\
\hline
\end{tabular}
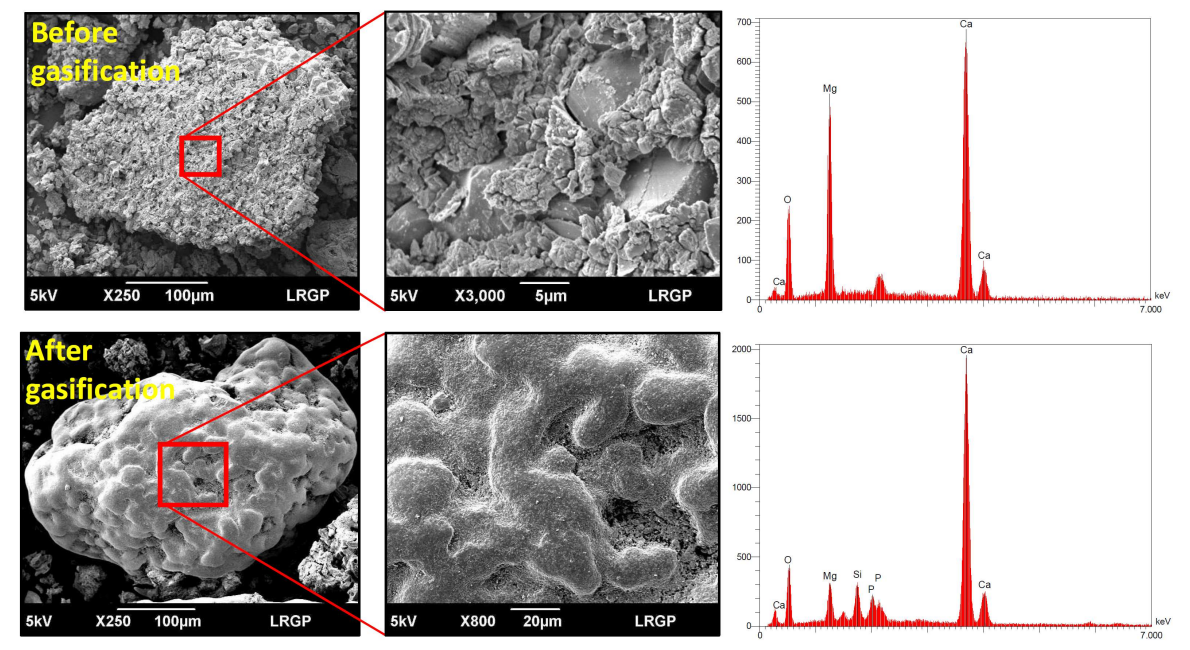

Figure 1. SEM-EDX analysis of the 2 dolomites (before and after biomass gasification in a pilot scale gasifier). SEM-EDX highlights the modification of the surface of particles which are coated by a layer of ashes during biomass gasification.

Table 3 presents the bulk chemical composition of the catalysts analyzed by ICP-MS. These results confirm that used catalysts were enriched in inorganic species during the biomass gasification. Fresh dolomite is mainly composed of $\mathrm{CaO}(50 \%)$ and $\mathrm{MgO}$ (38\%), with some traces of iron, silicium and aluminium (presented as oxides due to the ICP analysis). After gasification, used dolomite is mainly enriched in $\mathrm{SiO}_{2}$ (4.3 wt.\%, which is similar to EDX analysis) 
and $\mathrm{P}_{2} \mathrm{O}_{5}(0.39$ wt.\%, which is lower than EDX analysis). The two main species, $\mathrm{CaO}$ and $\mathrm{MgO}$, 228 were found to decrease mainly due to the increase of $\mathrm{SiO}_{2}$, while $\mathrm{Al}_{2} \mathrm{O}_{3}$ (1.02 wt.\%) slightly 229 increased in used dolomite. The loss on ignition increased for used dolomite (from 9.01 to $23011.88 \mathrm{wt} . \%)$ as a result of coke deposit and carbonates. Other species present in biomass ashes 231 (K, Mn, etc.) are also present in higher amount in the used dolomite which is in agreement with 232 ash composition of biomass (presented in supplementary material). Ash composition depends on 233 biomass type and culture mode but these elements are often found as the main inorganic 234 elements of many ligno-cellulosic biomasses. Therefore this ash coating is representative and 235 significant for the gasification of various biomasses in air-dense fluidized bed.

Table 3. Elemental composition of fresh and used dolomite (obtained by ICP-MS).

\begin{tabular}{lll}
\hline Element (wt. \%) & Fresh dolomite & Used dolomite \\
\hline Loss on ignition (wt. \%) & 9.01 & 11.88 \\
\hline $\mathrm{SiO}_{2}$ & 0.53 & 4.35 \\
$\mathrm{Al}_{2} \mathrm{O}_{3}$ & 0.26 & 1.02 \\
$\mathrm{Fe}_{2} \mathrm{O}_{3}$ & 0.39 & 0.43 \\
$\mathrm{MnO}$ & 0.02 & 0.14 \\
$\mathrm{MgO}$ & 38.30 & 34.16 \\
$\mathrm{CaO}$ & 50.13 & 47.20 \\
$\mathrm{Na}_{2} \mathrm{O}$ & 0.02 & 0.04 \\
$\mathrm{~K}_{2} \mathrm{O}$ & 0.01 & 0.28 \\
$\mathrm{TiO}_{2}$ & 0.02 & 0.05 \\
$\mathrm{P}_{2} \mathrm{O}_{5}$ & 0.03 & 0.39 \\
\hline
\end{tabular}

\subsubsection{XRD characterization of the catalysts}

As observed in Figure 2, the diffraction peaks of fresh dolomite show the presence of

242 periclase $(\mathrm{MgO})$, lime $(\mathrm{CaO})$, and portlandite $\left(\mathrm{Ca}(\mathrm{OH})_{2}\right)$. The peaks representative of dolomite 243 structure $\left(\mathrm{CaMg}\left(\mathrm{CO}_{3}\right)_{2}\right)$ are not detected. This crystalline modification can be explained by the 244 effect of the calcination treatment initially applied to this material, which is in agreement with 245 previous studies [45,65]. The XRD spectrum of used dolomite reveals the formation of 246 significant amounts of quartz $\left(\mathrm{SiO}_{2}\right)$ and traces of corundum $\left(\mathrm{Al}_{2} \mathrm{O}_{3}\right)$. This evolution corroborates 247 the ICP and SEM-EDX results demonstrating the enrichment of ash-based species in dolomite 248 particles during biomass gasification. XRD analysis also shows a relative decrease of $\mathrm{MgO}$ vs.

$249 \mathrm{CaO}$ in used dolomite. A small peak of calcite is detected in the used dolomite probably due to a 250 limited carbonation at $750^{\circ} \mathrm{C}$ in the gasifier (around $15 \%$ vol. of $\mathrm{CO}_{2}$ at the exit of the fluidised 251 bed). 


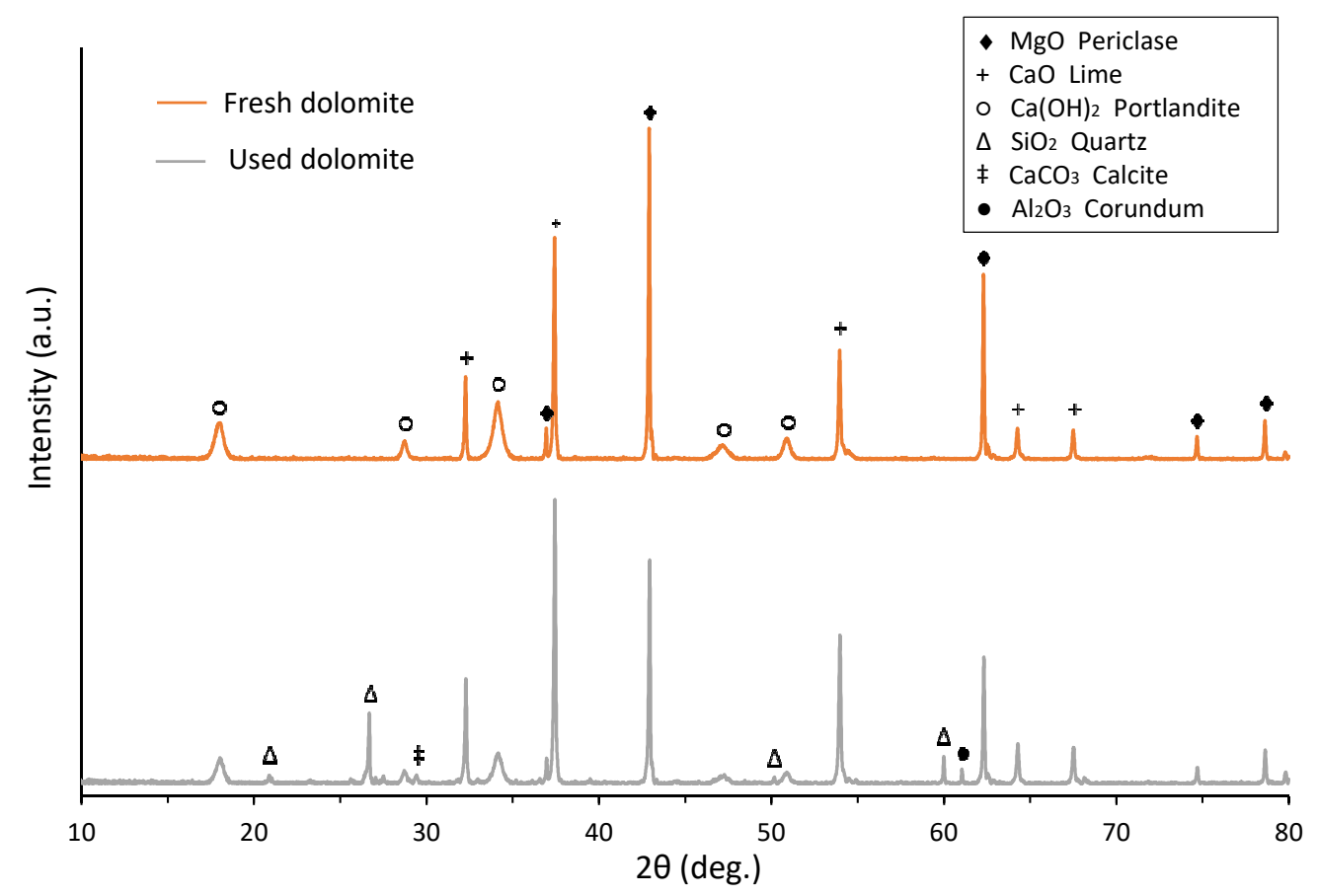

Figure 2. Diffractogram of the fresh and used dolomites

\subsubsection{Composition of the surface by XPS}

The XPS results are presented in Table 4. Binding energy (BE) and atomic concentration $(\%)$ were ascribed to the element according to published data $[45,94,95]$.

For fresh dolomite, the binding energies of the C $1 s$ signal (Table 4) highlight the presence of various carbonaceous species: graphitic or/and aliphatic hydrocarbons (C-C, C-H) at $284.6 \mathrm{eV}$, ethers $(\mathrm{C}-\mathrm{O})$ at $286.02 \mathrm{eV}$, aldehydes or carboxylic acids $(\mathrm{C}=\mathrm{O})$ at $287.89 \mathrm{eV}$, and carbonates $\left(\left(\mathrm{CO}_{3}\right)^{2-}\right)$ at $289.40 \mathrm{eV}$. Carbonates are part of the dolomite composition and are present in higher relative amount on the surface than in the bulk (as shown by XRD) mainly explained by the exposure to air (at room temperature) of the decarbonated samples. The other carbon species than carbonates may be attributed to carbonaceous deposit [94].

Two oxygen species were observed through the $\mathrm{O} 1 \mathrm{~s}$ binding energies at $531.17 \mathrm{eV}$ and $532.80 \mathrm{eV}$. The first one corresponds to $\mathrm{O}-\mathrm{C}$ or $\mathrm{O}-\mathrm{H}$ bonds, related to the presence of both carbonaceous and hydroxyl species [95]. These 2 types of bonds unfortunately cannot be discriminated. The second $\mathrm{O} 1 \mathrm{~s}$ signal at $532.80 \mathrm{eV}$ is generally attributed to chemisorbed water [95]. However, the high percentage of $40.47 \%$ is much higher than that of the carbonaceous species identified by the $\mathrm{C}-\mathrm{O}$ bonding at $286.02 \mathrm{eV}$. Therefore the $\mathrm{O} 1 \mathrm{~s}$ binding at $531.17 \mathrm{eV}$ may rather correspond to structural hydroxyls of the fresh catalyst. Its surface would be highly hydroxylated probably due to room temperature storage. 
The $\mathrm{Mg} 2 p$ and $\mathrm{Ca} 2 p$ signals correspond to surface concentrations (13.56 and $1.86 \%$ 275 respectively) much lower than the bulk oxides as analyzed by ICP. This result may be related to 276 the highly hydroxylated surface of the catalyst.

While iron and aluminium were observed in the bulk by ICP ( 0.4 and $1.0 \%$, respectively), 278 these elements are not detected at the surface of dolomite by XPS (before and after gasification). 279 Their content may be beyond the detection limit of the XPS technique, or these species could be mainly located in the bulk and not at the external surface analysed by XPS.

Concerning the used dolomite, silica species are found at the surface $(1.0 \%)$ which is consistent with SEM-EDX analysis. The $\mathrm{Mg} 2 p$ and $\mathrm{Ca} 2 p$ intensity peaks decrease after gasification: their atomic ratio dropped from 13.56 to 9.72 at.\% for $\mathrm{Ca}$, and from 1.86 to 1.00 at. \% for $\mathrm{Mg}$ (Table 4). This relative decrease in $\mathrm{Ca}$ and $\mathrm{Mg}$ is consistent with the bulk analysis by ICP measurements (Table 3).

Table 4. XPS analysis of fresh and used dolomites

\begin{tabular}{|c|c|c|c|c|}
\hline \multirow{2}{*}{ Element } & \multicolumn{2}{|c|}{ Fresh Dolomite } & \multicolumn{2}{|c|}{ Used Dolomite } \\
\hline & $\mathrm{BE}(\mathrm{eV})$ & at. $\%$ & $\mathrm{BE}(\mathrm{eV})$ & at. $\%$ \\
\hline $\mathrm{O}$ 1s O-C/O-H & 531.17 & 40.47 & 532.16 & 27.59 \\
\hline $\mathrm{O} 1 \mathrm{~s} \mathrm{H}_{2} \mathrm{O}$ & 532.80 & 5.33 & 533.66 & 6.68 \\
\hline C 1s C-(C,H) & 284.60 & 23.88 & 284.59 & 23.00 \\
\hline $\begin{array}{l}\text { C 1s C-OR, C- } \\
\mathrm{OH}, \mathrm{C}-\mathrm{O}\end{array}$ & 286.02 & 3.32 & 285.72 & 16.49 \\
\hline $\mathrm{C} 1 \mathrm{~s} C=\mathrm{O}$ & 287.89 & 1.25 & 287.14 & 5.75 \\
\hline $\mathrm{C} 1 \mathrm{~s} \mathrm{CO}_{3}{ }^{-2}$ & 289.40 & 10.33 & 290.24 & 8.74 \\
\hline $\mathrm{Ca} 2 \mathrm{p}$ & 346.80 & 13.56 & 347.75 & 9.72 \\
\hline $\operatorname{Mg} 2 p$ & 49.40 & 1.86 & 50.35 & 1.03 \\
\hline Si $2 p$ & - & - & 101.25 & 1.00 \\
\hline
\end{tabular}

The evolution of the oxygenated and carbonaceous species observed with XPS after gasification is illustrated in Figure 3. After gasification the atomic concentration of carbon at the surface of used dolomite significantly increases (from 38.8 to 53.9 wt.\%), and the concentration of oxygen drops from 45.8 to 34.3 wt.\%. Carbonaceous species containing ethers or carboxylic functions strongly increase after gasification (from 3.32 to $16.49 \%$, and from 1.25 to $5.75 \%$, respectively) probably due to oxygenated carbon deposit (Table 4). The content of hydrocarbons originally contained in the dolomite structure (C 1s C- $(\mathrm{C}-\mathrm{H})$ ) is almost unchanged. The concentration of carbonates $\left(\mathrm{C} 1 \mathrm{~s} \mathrm{CO}_{3}^{2-}\right)$ ) decreases a little after gasification. $\mathrm{O}$ 1s signal considerably decreases after gasification. Globally, after gasification, the surface becomes richer in C-O species and poorer in $\mathrm{Ca}-\mathrm{O}$ and $\mathrm{Mg}-\mathrm{O}$. 

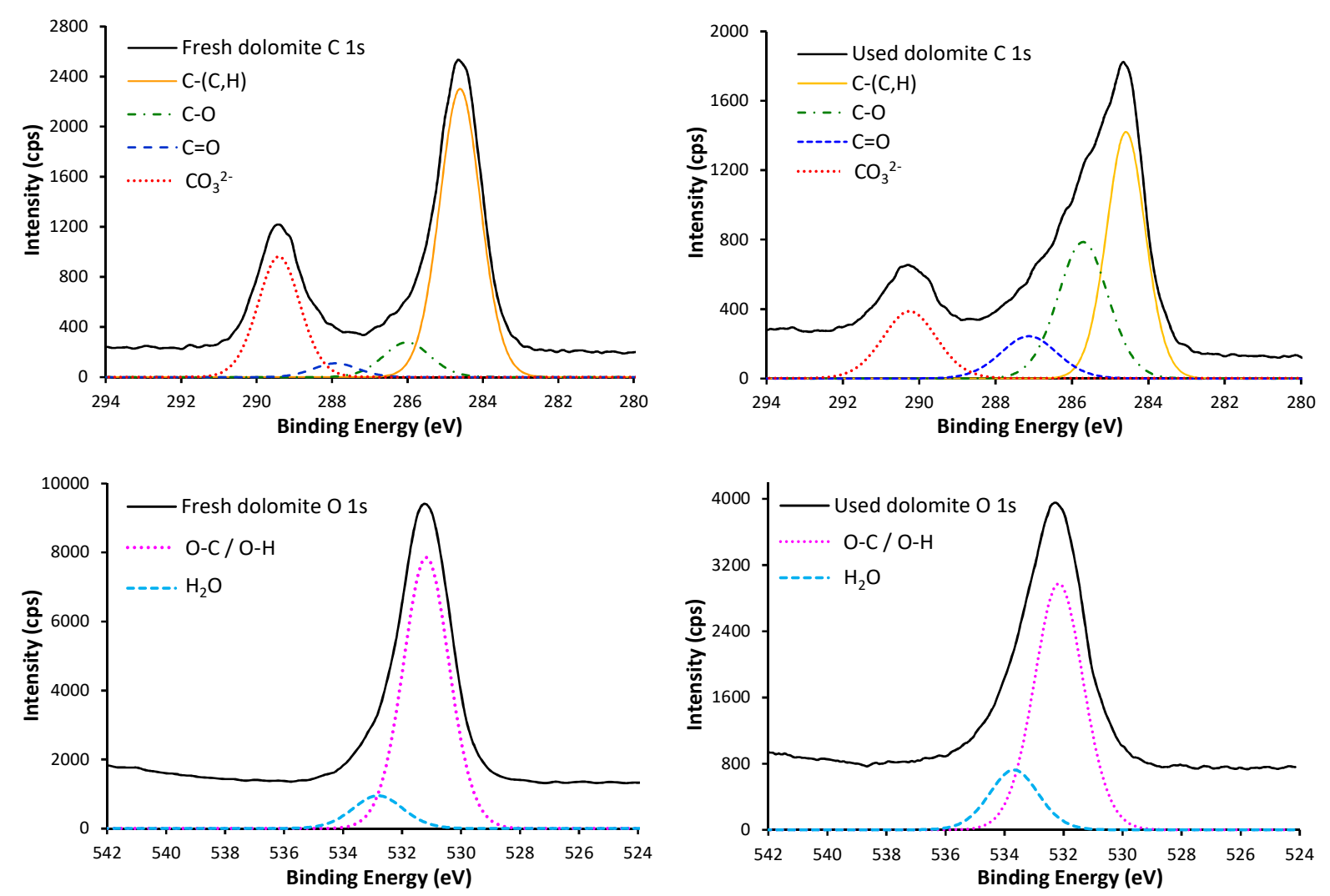

Figure 3. XPS spectra of carbon (C 1s) and oxygen (O 1s) species analysed on fresh dolomite and used dolomite after gasification.

TPD and TPO experiments were performed in order to complete these XPS analysis and to get a better insight on the nature of carbonaceous species present in fresh and used dolomites.

\subsubsection{TPD and TPO characterizations}

The amounts of $\mathrm{CO}_{2}$ released by fresh and used dolomite during TPD and TPO analysis are presented in Figure 4 (A) and (B) respectively.

No carbon monoxide was released during these analyses. During TPD (Figure 4A), both samples display a single $\mathrm{CO}_{2}$ peak occurring at a similar temperature (between 500 and $750^{\circ} \mathrm{C}$ ). The maximum peak is at $660^{\circ} \mathrm{C}$ and $715^{\circ} \mathrm{C}$ for fresh dolomite and used dolomite, respectively. The $\mathrm{CO}_{2}$ release obtained under pure nitrogen atmosphere is attributed to the decomposition of carbonates present in both samples. It can be noted that the amount of $\mathrm{CO}_{2}$ desorbed was

312 significantly higher for the used dolomite, which could be explained by the formation of 313 carbonates during the gasification reactions. This is in agreement with XRD analysis (Figure 2). for used dolomite (Figure 4B). This peak results from the oxidation of a reactive carbon 
316 produced during gasification. In addition, a $\mathrm{CO}_{2}$ peak similar to that obtained during the TPD

317 tests is observed for both samples. However, for used dolomite, the maximum of this peak is

318 achieved at slightly higher temperature than during TPD $\left(790^{\circ} \mathrm{C}\right.$ vs $\left.715^{\circ} \mathrm{C}\right)$, and the amount of

$319 \mathrm{CO}_{2}$ released is much higher. This difference can be attributed to the oxidation of a more stable coke produced during the gasification reactions and oxidized at high temperature $\left(\approx 800^{\circ} \mathrm{C}\right)$. To the best of our knowledge we present here the first TPO analysis of a dolomite used in a pilot scale gasifier during a significant time (10 days).

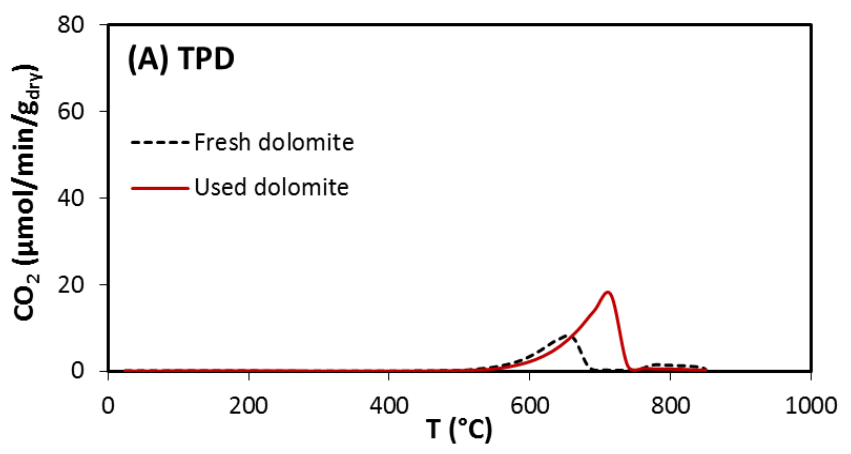

325

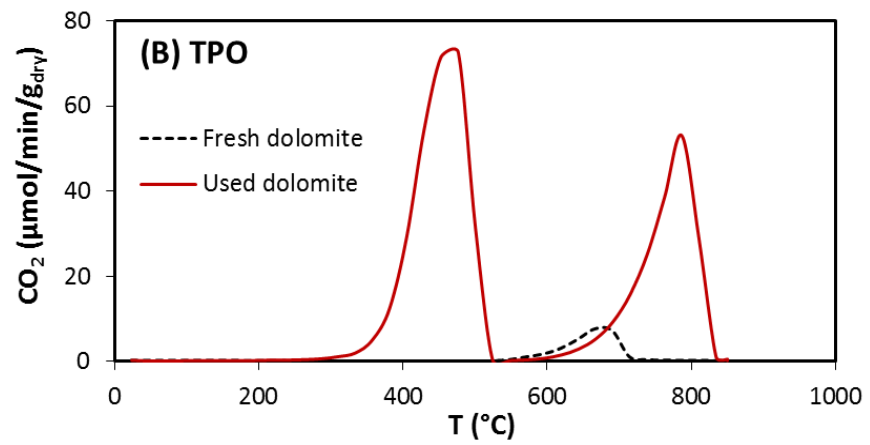

Figure 4. (A) TPD and (B) TPO analysis of fresh and used dolomites.

It is interesting to notice that similar ratios of carbonates to total carbon $\left[\mathrm{C}_{\text {Carbonates }} / \mathrm{C}_{\text {total }}\right]$ were found between TPD/TPO $\left(\mathrm{C}_{\text {Carbonates }} / \mathrm{C}_{\text {total }}=0.13\right)$ and XPS $\left(\mathrm{C}_{\text {Carbonates }} / \mathrm{C}_{\text {total }}=0.16\right)$ for the used dolomite. This would mean that the evolution of $\mathrm{CO}_{2}$ analysed during TPD/TPO may account for the decomposition of functions (carbonates and coke deposit) which are mainly formed at the external surface of particles during biomass gasification.

\subsection{Steam reforming of benzene over fresh and used dolomites}

In order to "probe" the reactivity of the two dolomite samples, their catalytic activity for benzene steam reforming were compared at three temperatures $\left(800,850\right.$ and $\left.900^{\circ} \mathrm{C}\right)$. The evolution of benzene conversion is presented in Figure 5. 
For both dolomites, the increase in temperature increases the benzene conversion.

339 Indeed, the conversion of benzene is multiplied by 3.5 between 800 and $900^{\circ} \mathrm{C}$. It is interesting 340 to note that used dolomite is less active than the fresh one. The activity of used dolomite 341 decreases by about $25 \%$ compared to the fresh sample. At $900^{\circ} \mathrm{C}$ the conversion of benzene obtained with fresh dolomite reaches $70 \%$ against $54 \%$ with used dolomite.

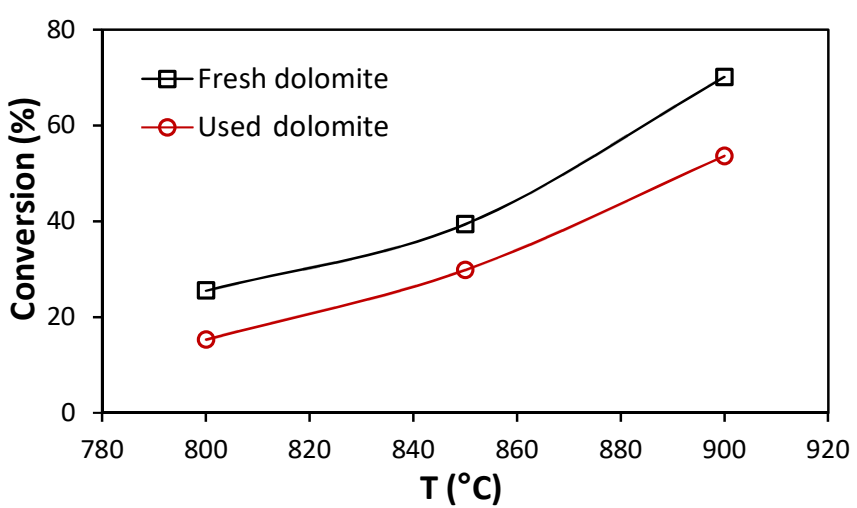

Figure 5. Effect of temperature and dolomite aging on benzene conversion during steam reforming $\left(\mathrm{C}_{6} \mathrm{H}_{6}=0.5 \mathrm{vol} \%, \mathrm{H}_{2} \mathrm{O}=22.2 \mathrm{vol}^{2} \%\right.$ in $\mathrm{N}_{2}, 3 \mathrm{~g}$ dolomite, $45 \mathrm{NmL} / \mathrm{min}$ total flow rate).

To assess the effect of aging on the reaction mechanisms, the selectivity on reaction products has been determined (Table 5). Similar gaseous species were produced by fresh and used dolomites: $\mathrm{H}_{2}, \mathrm{CO}_{2}, \mathrm{CO}$, and $\mathrm{CH}_{4}$. For both samples, the main products were $\mathrm{H}_{2}$ and $\mathrm{CO}_{2}$. Traces of $\mathrm{C}_{2} \mathrm{H}_{4}$ were produced by steam reforming of benzene only over the fresh dolomite.

For fresh dolomite, rising temperature from 800 to $900^{\circ} \mathrm{C}$ results in a decrease of $\mathrm{H}_{2}$ ($3.9 \%)$ and $\mathrm{CO}_{2}(-2.3 \%)$ selectivities at the expense of $\mathrm{CO}(+3.7 \%)$ and $\mathrm{CH}_{4}(+2.5 \%)$. This means that the overall selectivity in products is not mainly controlled by the thermodynamic equilibrium of the water gas-shift reaction which promotes $\mathrm{H}_{2}$ and $\mathrm{CO}_{2}$ at lower temperatures. The increase in $\mathrm{CO} / \mathrm{CO}_{2}$ with temperature is in agreement with results reported by Constantinou et al. in a stream rich in $\mathrm{H}_{2}$ [45]. At higher temperature, the cracking reaction of benzene forming $\mathrm{CH}_{4}$ seems to be promoted. The decrease in $\mathrm{H}_{2}$ selectivity with temperature may be linked to the higher selectivity in $\mathrm{CH}_{4}$. Further discussion is provided after the presentation of a potential mechanism of benzene reforming over dolomites in the next section. 
Table 5. Molar selectivity of the products generated by steam reforming of benzene.

\begin{tabular}{|c|c|c|c|c|c|c|c|c|c|c|c|c|c|c|c|}
\hline \multirow[b]{2}{*}{$\mathrm{T}\left({ }^{\circ} \mathrm{C}\right)$} & \multicolumn{3}{|c|}{$\mathrm{H}_{2}(\mathrm{~mol} \%)$} & \multicolumn{3}{|c|}{$\mathrm{CO}_{2}\left(\mathrm{~mol}^{2} \%\right)$} & \multicolumn{3}{|c|}{$\mathrm{CO}(\mathrm{mol} \%)$} & \multicolumn{3}{|c|}{$\mathrm{CH}_{4}(\mathrm{~mol} \%)$} & \multicolumn{3}{|c|}{$\mathrm{C}_{2} \mathrm{H}_{4}(\mathrm{~mol} \%)$} \\
\hline & 800 & 850 & 900 & 800 & 850 & 900 & 800 & 850 & 900 & 800 & 850 & 900 & 800 & 850 & 900 \\
\hline Fresh dolomite & 66.9 & 65.8 & 63.0 & 25.7 & 25.2 & 23.4 & 1.9 & 3.1 & 5.6 & 3.0 & 4.4 & 5.5 & 0.8 & 0.9 & 0.6 \\
\hline Used dolomite & 65.5 & 66.9 & 66.5 & 30.7 & 27.4 & 22.4 & 2.6 & 3.5 & 8.3 & 1.2 & 2.2 & 2.9 & 0.0 & 0.0 & 0.0 \\
\hline
\end{tabular}

Concerning the used dolomite, the evolutions of $\mathrm{CO}_{2}$ and $\mathrm{CO}$ are more significant with rising temperature: $-8.3 \%$ and $+5.6 \%$, respectively. Contrary to the fresh dolomite, the selectivity in $\mathrm{H}_{2}$ was almost constant with rising temperature. This finding confirms that the equilibrium of water gas-shift reaction does not control the global selectivity in $\mathrm{CO}_{2} / \mathrm{H}_{2} / \mathrm{CO}$ in this case. The steam gasification of coke present in the used dolomite (deposited during biomass gasification and as analyzed by TPO) may also contribute the higher selectivity in $\mathrm{H}_{2}$ and $\mathrm{CO}$ notably at $900^{\circ} \mathrm{C}$. More complex phenomena occur and will be detailed in the next section. The selectivities in $\mathrm{CH}_{4}$ and in $\mathrm{C}_{2} \mathrm{H}_{4}$ are lower for the used dolomites. This result may be explained by a lower cracking rate of benzene over the used dolomite.

\subsection{Discussion on the reaction mechanisms}

374 In a deep study Alarcon et al. have proposed a detailed mechanism for the steam reforming of 375 aromatics over $\mathrm{CaO}$ and $\mathrm{MgO}$ [68]. These authors have proposed, by analogy with the mechanism of hydrocarbons steam-reforming over metal supported catalysts [96], that aromatic hydrocarbons reforming over $\mathrm{CaO}$ or $\mathrm{MgO}$ catalysts would take place in two main step [94]: (i) the decomposition of the hydrocarbon and the water on the catalyst surface, and then (ii) the gasification of the deposited carbon with steam. The overall process could be written according to the following simplified mechanism: dolomite). The deposit $\left(\mathrm{C}_{\mathrm{x}} \mathrm{H}_{\mathrm{y}^{-}}\right)$may also decompose into smaller fragments and further form $\mathrm{H}_{2}$, $\mathrm{CH}_{4}$, and $\mathrm{C}_{\mathrm{x}}[68,94]$.

The decomposition of water molecules to hydrogen is easy over metal supported catalyst

$$
\begin{aligned}
& \mathrm{ArH}+\star \rightarrow \mathrm{C}_{\mathrm{x}} \mathrm{H}_{\mathrm{y}}-\star \\
& \mathrm{H}_{2} \mathrm{O}+\star \rightarrow \mathrm{O}-\star+\mathrm{H}_{2} \\
& \mathrm{C}_{\mathrm{x}} \mathrm{H}_{\mathrm{y}} \star+\mathrm{O}-\star \rightarrow \mathrm{H}_{2}, \mathrm{CO}, \mathrm{CO}_{2}, \mathrm{CH}_{4}+2 \star
\end{aligned}
$$

where $\mathrm{ArH}$ is an aromatic hydrocarbon specie, $\star$ is a $\mathrm{M}^{2+} \mathrm{O}^{2-}$ unit (the active site in when the metal phase is a noble or transition metal [96]. This is much less likely to occur over the 
389 non-reducible $\mathrm{CaO}$ or $\mathrm{MgO}$ oxides, unless they contained catalytic traces of a transition metal (e; 390 g; iron). Contrary to the reaction (R2) proposed by a previous study, we rather think that gaseous $391 \mathrm{H}_{2}$ stems from the decomposition of gaseous water on the carbon fragments rather than from 392 the direct water decomposition on the metal oxides. In other words, the water molecules are 393 reduced by the surface carbon fragments but not by the fixed valence metal oxides.

394 Based on our results and on literature analysis [45,68,74,94,97], an overall mechanism of 395 benzene steam reforming over dolomite is proposed (Figure 6). 


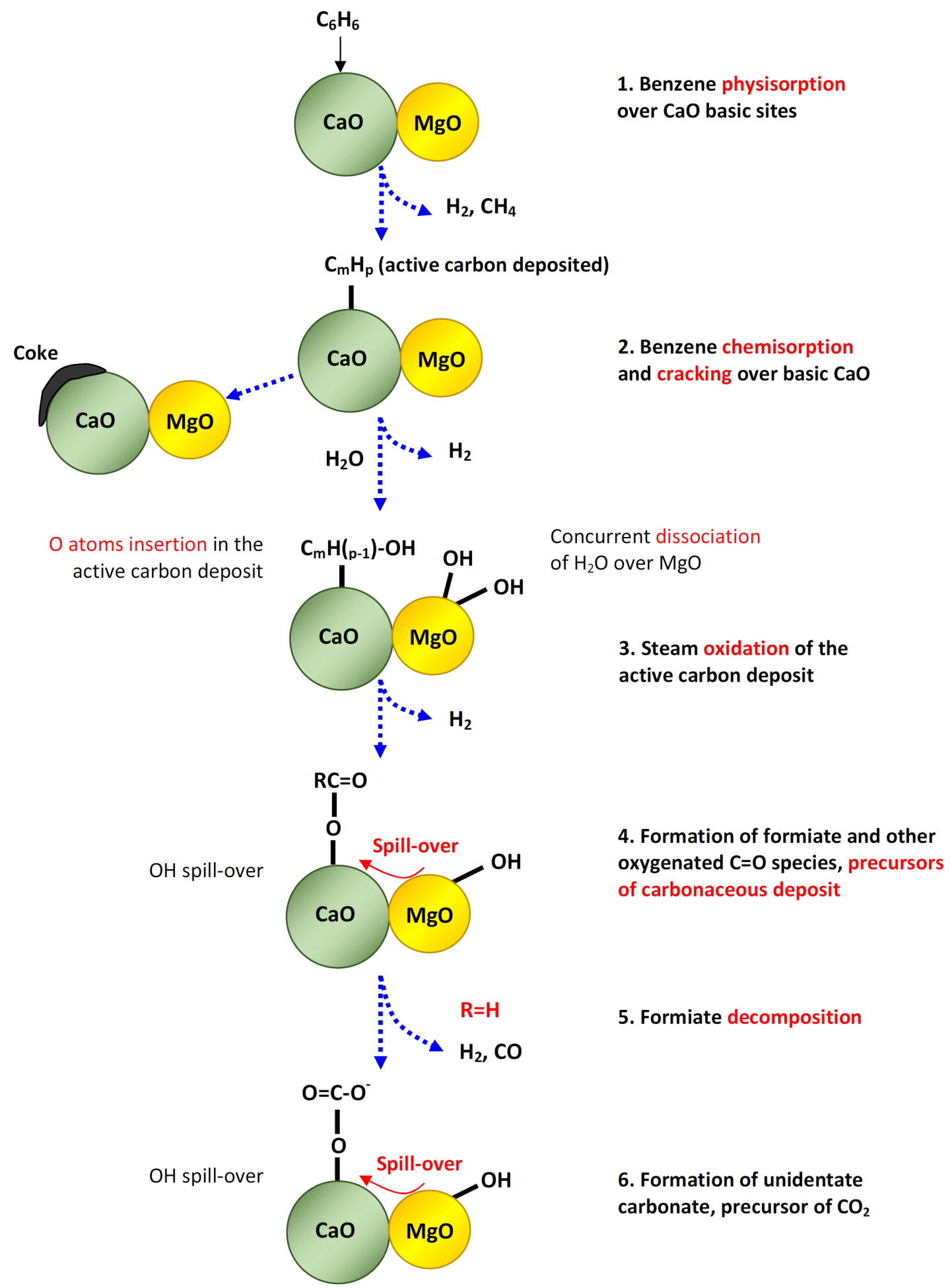

397 Figure 6. Chemical mechanism of benzene steam reforming over dolomite proposed based on the experimental results of the present study and on previous works [45,68,74,94,97]. 
on both minerals [98]. Moreover, van der Waals interactions increase the stability for all sites but more strongly on the Ca site. The benzene molecule was found to be adsorbed in a Ca hole, the aromatic ring forming an angle of 15 to $35^{\circ}$ with the surface. For $\mathrm{MgO}$, benzene adsorption takes place on weakly acidic $\mathrm{OH}$ groups, rather than on the $\mathrm{Mg}$ sites. The rate determining step of the steam-reforming of benzene over dolomite is the adsorption of the reactant hydrocarbon molecule [69]. This can be explained by the interactions between a neutral molecule and a strongly polarized solid surface. The stable and symmetrical benzene molecule is not easily polarizable, even with the highly ionic $\mathrm{CaO}$ or $\mathrm{MgO}$ dipoles. As a result, the chemical adsorption is weak and the Van der Waals interactions may become important [99]. From hard and soft acids and bases principles $[100,101]$, benzene is a soft base and $\mathrm{Ca}^{2+}$ a hard acid, also their interaction is fundamentally expected to be very poor. This interaction should be of van der Waals type, in good accordance with the theoretical investigation reported by Rigo et al. [98]. From these studies, it can be proposed that benzene is rather adsorbed and decomposed on the calcium oxide by interaction with the $\mathrm{Ca}^{++}$component (Figure 6).

Second, concerning the adsorption and role of water, $\mathrm{MgO}, \mathrm{CaO}$ and other non-reducible oxides (activated at high temperatures) exhibit the presence of highly basic $\mathrm{O}^{2-}$ sites [97]. The $\mathrm{OH}$ groups were shown to exist in the naphthalene steam-reforming reaction conditions over pure $\mathrm{MgO}$ or $\mathrm{MgO}+\mathrm{CaO}$ mixture, but not over pure $\mathrm{CaO}$ [68]. On the other hand, the introduction of steam results in the disappearance of the carbonaceous matter (mainly in the form of formiate species) from the surface of pure $\mathrm{MgO}$ and $\mathrm{MgO}$-containing mixture, while formiate species remains in the surface of $\mathrm{CaO}$ catalyst [68]. The authors concluded that the $\mathrm{OH}$ groups, stemming from $\mathrm{MgO}$, could participate both to the gaseous products formation and to coke removal. Chemically, it is impossible that anionic $\mathrm{OH}$ groups directly participate to the oxidation of carbons belonging to $\mathrm{C}-\mathrm{C}$ or $\mathrm{C}-\mathrm{H} \sigma$ bonds. Thus, $\mathrm{OH}^{-}$cannot be active species in the benzene steam-reforming. On the contrary, $\mathrm{H}_{2} \mathrm{O}$ may be responsible for the direct oxidation of hydrocarbons $\left(\mathrm{C}_{\mathrm{m}} \mathrm{H}_{(\mathrm{p}-1)}-\mathrm{OH}\right)$ (Figure 6). Due to its chemical properties, $\mathrm{OH}^{-}$can be reactive towards the oxidation of the carbon of $\mathrm{C}=\mathrm{O}$ double $\pi$ bonds of oxygenate species by a nucleophilic attack. The presence of these species over alkaline oxides were evidenced by Alarcon et al. [94]. These species disappear from the surface after the introduction of steam in the reactor over $\mathrm{MgO}$ or $\mathrm{CaO}+\mathrm{MgO}$, but not over pure $\mathrm{CaO}$. This led us to conclude that the role of $\mathrm{MgO}$ in $\mathrm{MgO}+\mathrm{CaO}$ mixture (and therefore in dolomite) is to bring the $\mathrm{OH}$ groups for the oxidation of oxygenate species deposited over $\mathrm{CaO}$ (after benzene sorption). This reaction would occur at the $\mathrm{MgO}-\mathrm{CaO}$ interface or through the spillover effect of the $\mathrm{OH}$ groups [102] (Figure 6). 
In an investigation on $\mathrm{MgO}$ [99] prepared from $\mathrm{Mg}(\mathrm{OH})_{2}$ precursor treated at various temperatures, it was shown that the surface $\mathrm{OH}$ concentration was similar for small or large $\mathrm{MgO}$ particles, but that the latter allowed more germinal $\mathrm{OH}$ pairs as well as $\mathrm{OH}$ surface island domains with weak Brönsted acidity. The reactivity of the $\mathrm{OH}$ groups is thus related to the morphology of $\mathrm{MgO}$ which, in turn, depends on the nature of the precursor and pre-treatments. This may contribute to the difference of reactivity of $\mathrm{MgO}$ in $\mathrm{MgO}+\mathrm{CaO}$ mechanical mixture, and dolomite.

Therefore in our proposed mechanism (Figure 6), the first step consists in the adsorption of benzene over the basic site of $\mathrm{CaO}[98]$ to form an active carbon deposit $\left(\mathrm{C}_{\mathrm{m}} \mathrm{H}_{\mathrm{p}}\right), \mathrm{C}_{\mathrm{x}} \mathrm{H}_{\mathrm{Y}}$ gas species (as analyzed in our work), and $\mathrm{H}_{2}$. Then, the active carbon deposit can produce coke. Water may either directly oxidize this active carbon deposit or may be dissociatively chemisorbed over $\mathrm{MgO}$ active site to form $\mathrm{OH}$ basic species. These $\mathrm{OH}$ basic species contribute to the formation of formiate and other oxygenate intermediates, then forming unidentate carbonate through OH spill-over. Formiate and carbonates have been analyzed by XPS in this present work and by infrared spectroscopy by Alarcon et al. [68,94] and Constantinou et al. [45]. This mechanism corroborates the results of Constantinou et al. [45] who demonstrated that $\mathrm{OH}$ species are important reaction intermediates for the conversion of aromatics into $\mathrm{C}_{\mathrm{x}}$ and $\mathrm{H}_{2}$. It has also been proved that unidentate carbonates are less stable than bicarbonates and constitute the main species formed over dolomite $[45,68,103]$. The former would be the precursors in $\mathrm{CO}_{2}$ formation.

The proposed mechanism supports our experimental results. When the temperature increases, the cracking of benzene promotes the formation of $\mathrm{C}_{\mathrm{x}} \mathrm{H}_{\mathrm{y}}$ gas species, especially over fresh dolomite. This reaction is less favored with the used dolomite probably due to the lower availability of $\mathrm{CaO}$ sites (as analyzed by XPS). The temperature increase is also associated to a decrease in $\mathrm{CO}_{2}$ and an increase in $\mathrm{CO}$ selectivities (Table 5). This evolution maybe explained by the cracking of benzene, as well as by the complex coupling between $\mathrm{OH}$ species formation and spill-over leading to $\mathrm{CO} / \mathrm{CO}_{2}$ (from formiate and carbonate intermediate). Carbon monoxide is generated by the thermal decomposition of formiate and higher homologs. This reaction was enhanced by increasing temperature, at the expense of the carbonates and $\mathrm{CO}_{2}$ route. Indeed, at high temperature, this route (formation of $\mathrm{OH}$ by $\mathrm{H}_{2} \mathrm{O}$ dissociation on $\mathrm{MgO}$ sites, and $\mathrm{OH}$ spillover) maybe slower than the formiate thermal decomposition microkinetic rate. Therefore the $\mathrm{OH}$ source may be limited leading to a lower formation of $\mathrm{CO}_{2}$ from carbonate. This effect is even more marked for the used dolomite since $\mathrm{MgO}$ sites, required for $\mathrm{OH}$ species formation, are expected to be less available. The $\mathrm{CO}_{2}$ route is also inhibited by increasing cracking reactions 
469 with rising temperature. Further studies are needed to study more deeply the detailed chemistry

470 of these intermediate $\mathrm{C}-\mathrm{O}$ species at the temperatures of hydrocarbons steam reforming.

471

472 For used dolomite, the deposit of coke and ashes, detected in this study by various 473 analytical tools, reduced the global availability of $\mathrm{CaO}$ and $\mathrm{MgO}$ active sites, as presented in the 474 simplified scheme in Figure 7.

475

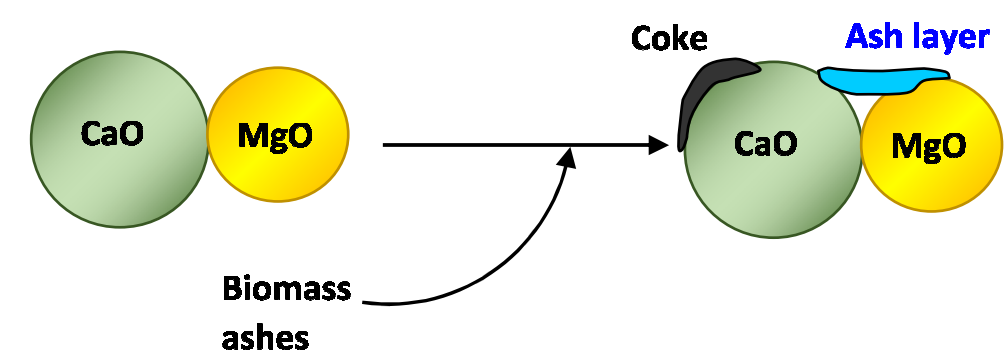

477 Figure 7. Deactivation of dolomites in biomass gasification reactors: the ashes formed from

478 biomass oxidation leads to a deposit of Si (and other species present in ashes) layer over 479 dolomite, and coke deposit also reduces the available active sites for benzene and water 480 adsorption. 


\section{Conclusion}

The evolution of dolomite surface chemistry during its use as bed material in a pilot-scale gasification reactor and its resulting activity on tar reforming have been studied for the first time.

487 Benzene steam reforming was selected as a model reaction in order to probe the activity of the 488 dolomites. surface properties of used dolomites. After being used as a bed material, used dolomite was covered by a layer rich in Si from biomass ash. In addition, coke was deposited at the used dolomite surface after gasification reactions.

The catalytic activity of used dolomite was $\approx 24 \%$ lower than that of fresh dolomite. This

494 drop in catalytic activity can be attributed to the Si-rich layer covering the surface of used

495 dolomite together with the coke deposition which decreased the availability of the active sites $496(\mathrm{CaO}, \mathrm{MgO})$. In addition, $\mathrm{SiO}_{2}$ has low catalytic activity towards tar reforming reactions. The $497 \mathrm{SiO}_{2}$ and coke deposition could also limit the interactions between $\mathrm{CaO}$ and $\mathrm{MgO}$, thus allowing the production of stable coke deactivating the catalyst.

This study presents a methodological approach that can be further used to study the

500 effect of different operating conditions during biomass gasification on the activity and 501 composition of dolomites (or other materials). Based on our experimental results and on the 502 literature data, a new reaction mechanism of benzene steam reforming on fresh and used 503 dolomite was proposed.

\section{Acknowledgements}

506 The ANR agency is thanked for a part of the financial support through the project Gameco 507 (coordinated by EDF). EDF (O. Authier) is acknowledged for having promoted this study and 508 EQTEC for providing the dolomite materials. 
512 [1] A.V. Bridgwater, Renewable fuels and chemicals by thermal processing of biomass, Chem. Eng. J. 91 (2003) 87-102.

[2] T.A. Milne, R.. Evans, N. Abatzoglou, Biomass Gasifier Tars: Their Nature, Formation and Conversion., National Renewable Energy Laboratory, 1998.

[3] G. Lardier, J. Kaknics, A. Dufour, R. Michel, B. Cluet, O. Authier, J. Poirier, G. Mauviel, Gas and Bed Axial Composition in a Bubbling Fluidized Bed Gasifier: Results with Miscanthus and Olivine, Energy Fuels. 30 (2016) 8316-8326. doi:10.1021/acs.energyfuels.6b01816.

[4] M. Nowakowska, O. Herbinet, A. Dufour, P.-A. Glaude, Kinetic Study of the Pyrolysis and Oxidation of Guaiacol, J. Phys. Chem. A. (2018). doi:10.1021/acs.jpca.8b06301.

[5] R. Coll, J. Salvadó, X. Farriol, D. Montané, Steam reforming model compounds of biomass gasification tars: conversion at different operating conditions and tendency towards coke formation, Fuel Process. Technol. 74 (2001) 19-31. doi:10.1016/S0378-3820(01)00214-4.

[6] GE Jenbacher, Fuel gas quality, special gases, 2009.

[7] L. Le Coq, A. Duga, Syngas treatment unit for small scale gasification-application to IC engine gas quality requirement, J. Appl. Fluid Mech. 5 (2012) 95-103.

[8] W. Torres, S.S. Pansare, J.G.G. Jr, Hot Gas Removal of Tars, Ammonia, and Hydrogen Sulfide from Biomass Gasification Gas, Catal. Rev. 49 (2007) 407-456. doi:10.1080/01614940701375134.

[9] D. Sutton, B. Kelleher, J.R. Ross, Review of literature on catalysts for biomass gasification, Fuel Process. Technol. 73 (2001) 155-173.

[10] P.J. Woolcock, R.C. Brown, A review of cleaning technologies for biomass-derived syngas, Biomass Bioenergy. 52 (2013) 54-84. doi:10.1016/j.biombioe.2013.02.036.

[11] M.L. Valderrama Rios, A.M. González, E.E.S. Lora, O.A. Almazán del Olmo, Reduction of tar generated during biomass gasification: A review, Biomass Bioenergy. 108 (2018) 345370. doi:10.1016/j.biombioe.2017.12.002.

[12] Y. Shen, K. Yoshikawa, Recent progresses in catalytic tar elimination during biomass gasification or pyrolysis-A review, Renew. Sustain. Energy Rev. 21 (2013) 371-392. doi:10.1016/j.rser.2012.12.062.

[13] Z. Abu El-Rub, E.A. Bramer, G. Brem, Review of Catalysts for Tar Elimination in Biomass Gasification Processes, Ind. Eng. Chem. Res. 43 (2004) 6911-6919. doi:10.1021/ie0498403.

[14] S. Anis, Z.A. Zainal, Tar reduction in biomass producer gas via mechanical, catalytic and thermal methods: A review, Renew. Sustain. Energy Rev. 15 (2011) 2355-2377. doi:10.1016/j.rser.2011.02.018.

[15] M. Asadullah, Barriers of commercial power generation using biomass gasification gas: A review, Renew. Sustain. Energy Rev. 29 (2014) 201-215. doi:10.1016/j.rser.2013.08.074.

[16] D.A. Bulushev, J.R.H. Ross, Catalysis for conversion of biomass to fuels via pyrolysis and gasification: A review, Catal. Today. 171 (2011) 1-13. doi:10.1016/j.cattod.2011.02.005.

[17] D. Dayton, A review of the literature on catalytic biomass tar destruction, NREL Rep. NRELTP-510-32815 NREL Gold. CO. (2002). http://gekgasifier.pbworks.com/f/CatalyticBiomassLitReview.pdf (accessed January 23, 2014).

[18] L. Devi, K.J. Ptasinski, F.J.J.G. Janssen, A review of the primary measures for tar elimination in biomass gasification processes, Biomass Bioenergy. 24 (2003) 125-140. doi:10.1016/S0961-9534(02)00102-2.

[19] G. Guan, M. Kaewpanha, X. Hao, A. Abudula, Catalytic steam reforming of biomass tar: Prospects and challenges, Renew. Sustain. Energy Rev. 58 (2016) 450-461. doi:10.1016/j.rser.2015.12.316. 
[20] J. Han, H. Kim, The reduction and control technology of tar during biomass gasification/pyrolysis: An overview, Renew. Sustain. Energy Rev. 12 (2008) 397-416. doi:10.1016/j.rser.2006.07.015.

[21] L. Devi, K.J. Ptasinski, F.J.J.G. Janssen, Pretreated olivine as tar removal catalyst for biomass gasifiers: investigation using naphthalene as model biomass tar, Fuel Process. Technol. 86 (2005) 707-730. doi:10.1016/j.fuproc.2004.07.001.

[22] A. Jess, Mechanisms and kinetics of thermal reactions of aromatic hydrocarbons from pyrolysis of solid fuels, Fuel. 75 (1996) 1441-1448. doi:10.1016/0016-2361(96)00136-6.

[23] C.M. Kinoshita, Y. Wang, J. Zhou, Tar formation under different biomass gasification conditions, J. Anal. Appl. Pyrolysis. 29 (1994) 169-181.

[24] A. Dufour, E. Masson, P. Girods, Y. Rogaume, A. Zoulalian, Evolution of Aromatic Tar Composition in Relation to Methane and Ethylene from Biomass Pyrolysis-Gasification, Energy Fuels. 25 (2011) 4182-4189. doi:10.1021/ef200846g.

[25] Y. Shen, J. Wang, X. Ge, M. Chen, By-products recycling for syngas cleanup in biomass pyrolysis - An overview, Renew. Sustain. Energy Rev. 59 (2016) 1246-1268. doi:10.1016/j.rser.2016.01.077.

[26] J. Park, Y. Lee, C. Ryu, Reduction of primary tar vapor from biomass by hot char particles in fixed bed gasification, Biomass Bioenergy. $90 \quad$ (2016) 114-121. doi:10.1016/j.biombioe.2016.04.001.

[27] D. Feng, Y. Zhao, Y. Zhang, Z. Zhang, L. Zhang, S. Sun, In-situ steam reforming of biomass tar over sawdust biochar in mild catalytic temperature, Biomass Bioenergy. 107 (2017) 261-270. doi:10.1016/j.biombioe.2017.10.007.

[28] M. Hervy, A. Villot, C. Gérente, D. Pham Minh, E. Weiss-Hortala, A. Nzihou, L. Le Coq, Catalytic cracking of ethylbenzene as tar surrogate using pyrolysis chars from wastes, Biomass Bioenergy. 117 (2018) 86-95. doi:10.1016/j.biombioe.2018.07.020.

[29] P.R. Buchireddy, R.M. Bricka, J. Rodriguez, W. Holmes, Biomass Gasification: Catalytic Removal of Tars over Zeolites and Nickel Supported Zeolites, Energy Fuels. 24 (2010) 2707-2715. doi:10.1021/ef901529d.

[30] D. Yao, H. Yang, H. Chen, P.T. Williams, Investigation of nickel-impregnated zeolite catalysts for hydrogen/syngas production from the catalytic reforming of waste polyethylene, Appl. Catal. B Environ. $227 \quad$ (2018) 477-487. doi:10.1016/j.apcatb.2018.01.050.

[31] M. Azhar Uddin, H. Tsuda, S. Wu, E. Sasaoka, Catalytic decomposition of biomass tars with iron oxide catalysts, Fuel. 87 (2008) 451-459. doi:10.1016/j.fuel.2007.06.021.

[32] J. Chen, M. Tamura, Y. Nakagawa, K. Okumura, K. Tomishige, Promoting effect of trace $\mathrm{Pd}$ on hydrotalcite-derived $\mathrm{Ni} / \mathrm{Mg} / \mathrm{Al}$ catalyst in oxidative steam reforming of biomass tar, Appl. Catal. B Environ. 179 (2015) 412-421. doi:10.1016/j.apcatb.2015.05.042.

[33] S.J. Juutilainen, P.A. Simell, A.O.I. Krause, Zirconia: Selective oxidation catalyst for removal of tar and ammonia from biomass gasification gas, Appl. Catal. B Environ. 62 (2006) 86-92. doi:10.1016/j.apcatb.2005.05.009.

[34] S. Cheah, K.R. Gaston, Y.O. Parent, M.W. Jarvis, T.B. Vinzant, K.M. Smith, N.E. Thornburg, M.R. Nimlos, K.A. Magrini-Bair, Nickel cerium olivine catalyst for catalytic gasification of biomass, Appl. Catal. B Environ. 134-135 (2013) 34-45. doi:10.1016/j.apcatb.2012.12.022.

[35] D.A. Constantinou, M.C. Álvarez-Galván, J.L.G. Fierro, A.M. Efstathiou, Low-temperature conversion of phenol into $\mathrm{CO}, \mathrm{CO} 2$ and $\mathrm{H} 2$ by steam reforming over La-containing supported Rh catalysts, Appl. Catal. B Environ. 117-118 (2012) 81-95. doi:10.1016/j.apcatb.2012.01.005.

[36] L. Wang, Y. Hisada, M. Koike, D. Li, H. Watanabe, Y. Nakagawa, K. Tomishige, Catalyst property of Co-Fe alloy particles in the steam reforming of biomass tar and toluene, Appl. Catal. B Environ. 121-122 (2012) 95-104. doi:10.1016/j.apcatb.2012.03.025. 
[37] D. Li, M. Tamura, Y. Nakagawa, K. Tomishige, Metal catalysts for steam reforming of tar derived from the gasification of lignocellulosic biomass, Bioresour. Technol. 178 (2015) 5364. doi:10.1016/j.biortech.2014.10.010.

[38] K. Raveendran, A. Ganesh, K.C. Khilar, Influence of mineral matter on biomass pyrolysis characteristics, Fuel. 74 (1995) 1812-1822. doi:10.1016/0016-2361(95)80013-8.

[39] N.B. Klinghoffer, M.J. Castaldi, A. Nzihou, Influence of char composition and inorganics on catalytic activity of char from biomass gasification, Fuel. 157 (2015) 37-47. doi:10.1016/j.fuel.2015.04.036.

[40] Y. Shen, P. Zhao, Q. Shao, D. Ma, F. Takahashi, K. Yoshikawa, In-situ catalytic conversion of tar using rice husk char-supported nickel-iron catalysts for biomass pyrolysis/gasification, Appl. Catal. B Environ. 152-153 (2014) 140-151. doi:10.1016/j.apcatb.2014.01.032.

[41] P.H. Blanco, C. Wu, J.A. Onwudili, P.T. Williams, Characterization and evaluation of $\mathrm{Ni} / \mathrm{SiO} 2$ catalysts for hydrogen production and tar reduction from catalytic steam pyrolysisreforming of refuse derived fuel, Appl. Catal. B Environ. 134-135 (2013) 238-250. doi:10.1016/j.apcatb.2013.01.016.

[42] J.N. Kuhn, Z. Zhao, L.G. Felix, R.B. Slimane, C.W. Choi, U.S. Ozkan, Olivine catalysts for methane- and tar-steam reforming, Appl. Catal. B Environ. 81 (2008) 14-26. doi:10.1016/j.apcatb.2007.11.040.

[43] M. Virginie, C. Courson, D. Niznansky, N. Chaoui, A. Kiennemann, Characterization and reactivity in toluene reforming of a $\mathrm{Fe}$ /olivine catalyst designed for gas cleanup in biomass gasification, Appl. Catal. B Environ. 101 (2010) 90-100. doi:10.1016/j.apcatb.2010.09.011.

[44] J.F. González, S. Román, G. Engo, J.M. Encinar, G. Martínez, Reduction of tars by dolomite cracking during two-stage gasification of olive cake, Biomass Bioenergy. 35 (2011) 4324-4330. doi:10.1016/j.biombioe.2011.08.001.

[45] D.A. Constantinou, J.L.G. Fierro, A.M. Efstathiou, A comparative study of the steam reforming of phenol towards $\mathrm{H}_{2}$ production over natural calcite, dolomite and olivine materials, Appl. Catal. B Environ. 95 (2010) 255-269. doi:10.1016/j.apcatb.2010.01.003.

[46] M.F. Tennant, D.W. Mazyck, Steam-pyrolysis activation of wood char for superior odorant removal, Carbon. 41 (2003) 2195-2202. doi:10.1016/S0008-6223(03)00211-2.

[47] A. Donnot, P. Magne, X. Deglise, Reactions of Dolomite with CO $<$ Subscript $>2</$ Subscript $>$ at Gasification Temperatures of Wood, in: Res. Thermochem. Biomass Convers., Springer, Dordrecht, 1988: pp. 1002-1015. doi:10.1007/978-94-009-2737-7_75.

[48] P. Pérez, P.M. Aznar, M.A. Caballero, J. Gil, J.A. Martín, J. Corella, Hot Gas Cleaning and Upgrading with a Calcined Dolomite Located Downstream a Biomass Fluidized Bed Gasifier Operating with Steam-Oxygen Mixtures, Energy Fuels. 11 (1997) 1194-1203. doi:10.1021/ef970046m.

[49] J. Corella, M.-P. Aznar, J. Gil, M.A. Caballero, Biomass Gasification in Fluidized Bed: Where To Locate the Dolomite To Improve Gasification?, Energy Fuels. 13 (1999) 11221127. doi:10.1021/ef990019r.

[50] J. Delgado, M.P. Aznar, J. Corella, Calcined dolomite, magnesite, and calcite for cleaning hot gas from a fluidized bed biomass gasifier with steam: life and usefulness, Ind. Eng. Chem. Res. 35 (1996) 3637-3643.

[51] G. Taralas, Effects of $\mathrm{MgO}, \mathrm{CaO}$ and calcined dolomites on model substance cracking and conversion of tar from biomass gasification/pyrolysis gas, Department of Chemical Technology - Royal Institute of Technology, Stockholm, 1990.

[52] P.A. Simell, E.K. Hirvensalo, V.T. Smolander, A.O.I. Krause, Steam Reforming of Gasification Gas Tar over Dolomite with Benzene as a Model Compound, Ind. Eng. Chem. Res. 38 (1999) 1250-1257. doi:10.1021/ie980646o. 
[53] H. Aldén, E. Björkman, M. Carlsson, L. Waldheim, Catalytic Cracking of Naphthalene on Dolomite, in: Adv. Thermochem. Biomass Convers., Springer, Dordrecht, 1993: pp. 216232. doi:10.1007/978-94-011-1336-6_17.

[54] P.A. Simell, N.A.K. Hakala, H.E. Haario, A.O.I. Krause, Catalytic decomposition of gasification gas tar with benzene as the model compound, Ind. Eng. Chem. Res. 36 (1997) 42-51.

[55] P.A. Simell, J.K. Leppälahti, E.A. Kurkela, Tar-decomposing activity of carbonate rocks under high CO2 partial pressure, Fuel. 74 (1995) 938-945. doi:10.1016/00162361(95)00012-T.

[56] E. Gusta, A.K. Dalai, M.A. Uddin, E. Sasaoka, Catalytic Decomposition of Biomass Tars with Dolomites, Energy Fuels. 23 (2009) 2264-2272. doi:10.1021/ef8009958.

[57] A. Sarığlan, Tar removal on dolomite and steam reforming catalyst: Benzene, toluene and xylene reforming, Int. J. Hydrog. Energy. $37 \quad$ (2012) 8133-8142. doi:10.1016/j.ijhydene.2012.02.045.

[58] R. Zhang, R.C. Brown, A. Suby, K. Cummer, Catalytic destruction of tar in biomass derived producer gas, Energy Convers. Manag. $45 \quad$ (2004) 995-1014. doi:10.1016/j.enconman.2003.08.016.

[59] J.M. de Andrés, A. Narros, M.E. Rodríguez, Behaviour of dolomite, olivine and alumina as primary catalysts in air-steam gasification of sewage sludge, Fuel. 90 (2011) 521-527. doi:10.1016/j.fuel.2010.09.043.

[60] P. Ammendola, B. Piriou, L. Lisi, G. Ruoppolo, R. Chirone, G. Russo, Dual bed reactor for the study of catalytic biomass tars conversion, Exp. Therm. Fluid Sci. 34 (2010) 269-274. doi:10.1016/j.expthermflusci.2009.10.019.

[61] D.C. Elliott, E.G. Baker, The effect of catalysis on wood-gasification tar composition, Biomass. 9 (1986) 195-203. doi:10.1016/0144-4565(86)90089-2.

[62] H. Aldén, B.-G. Espenäs, E. Rensfelt, Conversion of Tar in Pyrolysis Gas from Wood Using a Fixed Dolomite Bed, in: A.V. Bridgwater, J.L. Kuester (Eds.), Res. Thermochem. Biomass Convers., Springer Netherlands, Dordrecht, 1988: pp. 987-1001. doi:10.1007/97894-009-2737-7_74.

[63] K. Sjöström, G. Taralas, L. Liinanki, Sala Dolomite-Catalysed Conversion of Tar from Biomass Pyrolysis, in: A.V. Bridgwater, J.L. Kuester (Eds.), Res. Thermochem. Biomass Convers., Springer Netherlands, Dordrecht, 1988: pp. 974-986. doi:10.1007/978-94-0092737-7_73.

[64] P.A. Simell, J.K. Leppälahti, J.B. Bredenberg, Catalytic purification of tarry fuel gas with carbonate rocks and ferrous materials, Fuel. 71 (1992) 211-218. doi:10.1016/00162361(92)90011-C.

[65] G. Hu, S. Xu, S. Li, C. Xiao, S. Liu, Steam gasification of apricot stones with olivine and dolomite as downstream catalysts, Fuel Process. Technol. 87 (2006) 375-382. doi:10.1016/j.fuproc.2005.07.008.

[66] A.H. Clemens, L.F. Damiano, T.W. Matheson, The effect of calcium on the rate and products of steam gasification of char from low rank coal, Fuel. 77 (1998) 1017-1020. doi:10.1016/S0016-2361(97)00276-7.

[67] J. Delgado, M.P. Aznar, J. Corella, Biomass Gasification with Steam in Fluidized Bed: Effectiveness of $\mathrm{CaO}, \mathrm{MgO}$, and $\mathrm{CaO}-\mathrm{MgO}$ for Hot Raw Gas Cleaning, Ind. Eng. Chem. Res. 36 (1997) 1535-1543. doi:10.1021/ie960273w.

[68] N. Alarcón, X. Garc $\square$ a, M.A. Centeno, P. Ruiz, A. Gordon, New effects during steam gasification of naphthalene: the synergy between $\mathrm{CaO}$ and $\mathrm{MgO}$ during the catalytic reaction, Appl. Catal. Gen. 267 (2004) 251-265. doi:10.1016/j.apcata.2004.03.010.

[69] P.A. Simell, J.O. Hepola, A.O.I. Krause, Effects of gasification gas components on tar and ammonia decomposition over hot gas cleanup catalysts, Fuel. 76 (1997) 1117-1127. doi:10.1016/S0016-2361(97)00109-9. 
[70] G. Taralas, M.G. Kontominas, X. Kakatsios, Modeling the Thermal Destruction of Toluene (C7H8) as Tar-Related Species for Fuel Gas Cleanup, Energy Fuels. 17 (2003) 329-337. doi:10.1021/ef0201533.

[71] G. Taralas, M.G. Kontominas, Kinetic modelling of VOC catalytic steam pyrolysis for tar abatement phenomena in gasification/pyrolysis technologies, Fuel. 83 (2004) 1235-1245. doi:10.1016/j.fuel.2003.11.010.

[72] G. Lammers, A. a. C.M. Beenackers, J. Corella, Catalytic Tar Removal from Biomass Producer Gas with Secondary Air, in: Dev. Thermochem. Biomass Convers., Springer, Dordrecht, 1997: pp. 1179-1193. doi:10.1007/978-94-009-1559-6_95.

[73] H. Kobayashi, M. Yamaguchi, T. Ito, Ab initio MO study on adsorption of a hydrogen molecule onto magnesium oxide (100) surface, J. Phys. Chem. 94 (1990) 7206-7213. doi:10.1021/j100381a047.

[74] H. Hattori, Heterogeneous Basic Catalysis, Chem. Rev. 95 (1995) 537-558. doi:10.1021/cr00035a005.

[75] C.P.B. Quitete, M.M.V.M. Souza, Application of Brazilian dolomites and mixed oxides as catalysts in tar removal system, Appl. Catal. Gen. 536 (2017) 1-8. doi:10.1016/j.apcata.2017.02.014.

[76] S. Nakamura, S. Kitano, K. Yoshikawa, Biomass gasification process with the tar removal technologies utilizing bio-oil scrubber and char bed, Appl. Energy. 170 (2016) 186-192. doi:10.1016/j.apenergy.2016.02.113.

[77] P. Brandt, E. Larsen, U. Henriksen, High Tar Reduction in a Two-Stage Gasifier, Energy Fuels. 14 (2000) 816-819. doi:10.1021/ef990182m.

[78] Y. Shao, D. Meng, C.C. Xu, F. Preto, J. Zhu, Ash Deposition in Air-Blown Gasification of Peat and Woody Biomass in a Fluidized-Bed Gasifier, Energy Fuels. (2018). doi:10.1021/acs.energyfuels.8b00158.

[79] S. Rapagnà, K. Gallucci, P.U. Foscolo, Olivine, dolomite and ceramic filters in one vessel to produce clean gas from biomass, Waste Manag. 71 (2018) 792-800. doi:10.1016/j.wasman.2017.07.038.

[80] Y. Tian, X. Zhou, S. Lin, X. Ji, J. Bai, M. Xu, Syngas production from air-steam gasification of biomass with natural catalysts, Sci. Total Environ. 645 (2018) 518-523. doi:10.1016/j.scitotenv.2018.07.071.

[81] M. Jeremiáš, M. Pohořelý, K. Svoboda, S. Skoblia, Z. Beňo, M. Šyc, CO2 gasification of biomass: The effect of lime concentration in a fluidised bed, Appl. Energy. 217 (2018) 361368. doi:10.1016/j.apenergy.2018.02.151.

[82] S. Kern, C. Pfeifer, H. Hofbauer, Reactivity tests of the water-gas shift reaction on fresh and used fluidized bed materials from industrial DFB biomass gasifiers, Biomass Bioenergy. 55 (2013) 227-233. doi:10.1016/j.biombioe.2013.02.001.

[83] F. Kirnbauer, V. Wilk, H. Kitzler, S. Kern, H. Hofbauer, The positive effects of bed material coating on tar reduction in a dual fluidized bed gasifier, Fuel. 95 (2012) 553-562. doi:10.1016/j.fuel.2011.10.066.

[84] F. Kirnbauer, H. Hofbauer, Investigations on Bed Material Changes in a Dual Fluidized Bed Steam Gasification Plant in Güssing, Austria, Energy Fuels. 25 (2011) 3793-3798. doi:10.1021/ef200746c.

[85] F. Kirnbauer, H. Hofbauer, The mechanism of bed material coating in dual fluidized bed biomass steam gasification plants and its impact on plant optimization, Powder Technol. 245 (2013) 94-104.

[86] M. Kuba, F. Havlik, F. Kirnbauer, H. Hofbauer, Influence of bed material coatings on the water-gas-shift reaction and steam reforming of toluene as tar model compound of biomass gasification, Biomass Bioenergy. 89 (2016) 40-49. doi:10.1016/j.biombioe.2015.11.029. 
[87] M. Kuba, H. He, F. Kirnbauer, D. Boström, M. Öhman, H. Hofbauer, Deposit build-up and ash behavior in dual fluid bed steam gasification of logging residues in an industrial power plant, Fuel Process. Technol. 139 (2015) 33-41. doi:10.1016/j.fuproc.2015.08.017.

[88] M. Kuba, H. He, F. Kirnbauer, N. Skoglund, D. Boström, M. Öhman, H. Hofbauer, Mechanism of Layer Formation on Olivine Bed Particles in Industrial-Scale Dual Fluid Bed Gasification of Wood, Energy Fuels. $30 \quad$ (2016) 7410-7418. doi:10.1021/acs.energyfuels.6b01522.

[89] L. Coll, EQTEC GASIFIER TECHNOLOGY, in: Hamburg, Germany, 2014.

[90] J. Carignan, P. Hild, G. Mevelle, J. Morel, D. Yeghicheyan, Routine analyses of trace elements in geological samples using flow injection and low pressure on-line liquid chromatography and ICP-MS: A study of geochemichal reference materials BR, DR-N, UBN, AN-G and GH, Geostand. Geoanalytical Res. 25 (2001) 187-198.

[91] R.N. Olcese, M. Bettahar, D. Petitjean, B. Malaman, F. Giovanella, A. Dufour, Gas-phase hydrodeoxygenation of guaiacol over Fe/SiO2 catalyst, Appl. Catal. B Environ. 115-116 (2012) 63-73. doi:10.1016/j.apcatb.2011.12.005.

[92] J. Kaknics, R. Michel, J. Poirier, E. de Bilbao, Experimental Study and Thermodynamic Modelling of High Temperature Interactions Between Molten Miscanthus Ashes and Bed Particles in Fluidized Bed Reactors, Waste Biomass Valorization. 8 (2017) 2771-2790. doi:10.1007/s12649-017-9828-x.

[93] R. Michel, J. Kaknics, E. de Bilbao, J. Poirier, The mechanism of agglomeration of the refractory materials in a fluidized-bed reactor, Ceram. Int. 42 (2016) 2570-2581. doi:10.1016/j.ceramint.2015.10.060.

[94] N. Alarcón, X. García, M. Centeno, P. Ruiz, A. Gordon, Catalytic cooperation at the interface of physical mixtures of $\mathrm{CaO}$ and $\mathrm{MgO}$ catalysts during steam gasification of naphthalene, Surf. Interface Anal. 31 (n.d.) 1031-1041. doi:10.1002/sia.1137.

[95] V. Derycke, M. Kongolo, M. Benzaazoua, M. Mallet, O. Barrès, P. De Donato, B. Bussière, R. Mermillod-Blondin, Surface chemical characterization of different pyrite size fractions for flotation purposes, Int. J. Miner. Process. 118 (2013) 1-14. doi:10.1016/j.minpro.2012.10.004.

[96] A.P.E. York, T. Xiao, M.L.H. Green, J.B. Claridge, Methane Oxyforming for Synthesis Gas Production, Catal. Rev. 49 (2007) 511-560. doi:10.1080/01614940701583315.

[97] J.C. Lavalley, Infrared spectrometric studies of the surface basicity of metal oxides and zeolites using adsorbed probe molecules, Catal. Today. 27 (1996) 377-401. doi:10.1016/0920-5861(95)00161-1.

[98] V.A. Rigo, C.O. Metin, Q.P. Nguyen, C.R. Miranda, Hydrocarbon Adsorption on Carbonate Mineral Surfaces: A First-Principles Study with van der Waals Interactions, J. Phys. Chem. C. 116 (2012) 24538-24548. doi:10.1021/jp306040n.

[99] H. Itoh, S. Utamapanya, J.V. Stark, K.J. Klabunde, J.R. Schlup, Nanoscale Metal Oxide Particles as Chemical Reagents. Intrinsic Effects of Particle Size on Hydroxyl Content and on Reactivity and Acid/Base Properties of Ultrafine Magnesium Oxide, Chem. Mater. 5 (1993) 71-77. doi:10.1021/cm00025a015.

[100] R.G. Pearson, Acids and Bases, Science. 151 (1966) 172-177. doi:10.1126/science.151.3707.172.

[101] R.G. Pearson, Absolute electronegativity and hardness: application to inorganic chemistry, Inorg. Chem. 27 (1988) 734-740. doi:10.1021/ic00277a030.

[102] W.C. Conner, J.L. Falconer, Spillover in Heterogeneous Catalysis, Chem. Rev. 95 (1995) 759-788. doi:10.1021/cr00035a014.

[103] R. Philipp, K. Omata, A. Aoki, K. Fujimoto, On the active site of $\mathrm{MgO} / \mathrm{CaO}$ mixed oxide for oxidative coupling of methane, J. Catal. 134 (1992) 422-433. doi:10.1016/00219517(92)90332-C. 
Graphical abstract

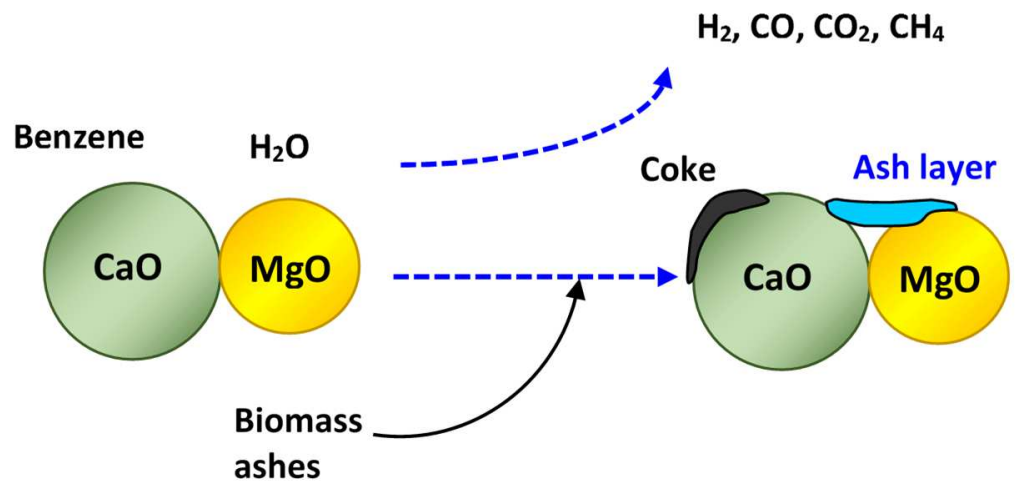

